\title{
Biofilm formation of Staphylococcus aureus dairy isolates representing different genotypes
}

\author{
E. Thiran, ${ }^{* 1}$ P. A. Di Ciccio, $\dagger^{1}$ H. U. Graber, ${ }^{*}$ E. Zanardi, $\dagger$ A. lanieri, $\dagger$ and J. Hummerjohann ${ }^{* 2}$ \\ *Unit of Microbial Systems of Food, Agroscope, Schwarzenburgstrasse 161, CH 3003 Berne, Switzerland \\ †Food and Drug Department, University of Parma, Via del Taglio 10, 43126, Parma, Italy
}

\section{ABSTRACT}

The objective of this study was to compare the biofilm-forming capabilities of different genotypes of Staphylococcus aureus dairy isolates from Switzerland and northern Italy, including Staph. aureus genotype B (GTB) and methicillin-resistant Staph. aureus (MRSA). We hypothesized that biofilm formation might be more pronounced in the contagious GTB isolates compared with other genotypes affecting individual animals. Twenty-four dairy isolates, including 9 MRSA, were further characterized by genotyping by using ribosomal spacer PCR, spa typing, biofilm formation under static and dynamic conditions, and scanning electron microscopy. The GTB isolates $(\mathrm{n}=6)$ were more able to form biofilms than other genotypes at $37^{\circ} \mathrm{C}$ and at $20^{\circ} \mathrm{C}$ after 48 and $72 \mathrm{~h}$ of incubation in the static assay using polystyrene microtiter plates. This result was supported by scanning electron micrographs showing a GTB isolate producing strong biofilm with extracellular matrix in contrast to a genotype $\mathrm{C}$ isolate. Furthermore, none of the MRSA isolates formed strong biofilms in the static assay. However, some MRSA produced low or moderate amounts of biofilm depending on the applied conditions. Under dynamic conditions, a much more diverse situation was observed. The ability of GTB isolates to be strong biofilm formers was not observed in all cases, emphasizing the importance of growth conditions for the expression of biofilm-related genes. No specific genotype, spa type, or MRSA isolate could be categorized significantly into one level of biofilm formation. Nineteen percent of isolates behaved similarly under static and dynamic conditions. The results of this study expand our knowledge of different dairy-related Staph. aureus subtypes and indicate the benefit of genotyping when biofilms are studied.

Received August 17, 2017.

Accepted September 22, 2017.

${ }^{1}$ These authors contributed equally to this work.

${ }^{2}$ Corresponding author: joerg.hummerjohann@agroscope.admin.ch
Key words: Staphylococcus aureus, biofilm, genotype, spa type

\section{INTRODUCTION}

Staphylococcus aureus is a foodborne pathogen considered the third most important causative bacterial agent of foodborne illnesses worldwide (Hennekinne et al., 2012); it is of great concern to the dairy industry (De Buyser et al., 2001; Oliver et al., 2009). In particular, dairy cow mastitis is the most important disease in the global dairy industry and Staph. aureus is one of the most important etiological agents of contagious mastitis (Silva et al., 2013; Voelk et al., 2014). Another major concern is that Staph. aureus can form biofilms (Santos et al., 2014). Biofilms are aggregates of microbial cells surrounded by a matrix of exopolymers (Costerton et al., 1999). Besides the production of exotoxins and surface proteins, the formation of these highly organized multicellular complexes is increasingly recognized as an important virulence factor in Staph. aureus (Tang et al., 2012; Lee et al., 2014). Biofilm formation can lead to persistent contamination or infection because the cells within the biofilm are very resistant to sanitation procedures and to the action of the host immune system and antimicrobial agents (Song et al., 2016). Different sources of Staph. aureus in the dairy cow environment have been described (Zadoks et al., 2002). Infected animals (cow-to-cow transmission), workers, and equipment and utensils used for milking are the main sources of the microorganism (Lee et al., 2014). Although some researchers have studied the ability of members of the Staphylococcus genus to adhere to surfaces and form biofilm, most studies have addressed the clinical aspects related to biofilm formation by Staphylococcus intermedius on medical implants and materials (Donlan and Costerton, 2002; de Souza et al., 2014). Moreover, few studies have reported biofilm formation by Staph. aureus isolated from ready-to-eatfoods (Oniciuc et al., 2016). Additionally, recent studies have identified several genotypes of Staph. aureus that differ in their contagiosity and pathogenicity (Fournier 
et al., 2008; Voelk et al., 2014; Cosandey et al., 2016). Graber et al. (2009) further demonstrated that genotype was highly associated with virulence gene pattern. Among different genotypes, Staph. aureus genotype B (GTB) is associated with high within-herd prevalence, indicating an increased contagious and virulence potential compared with other genotypes (Graber et al., 2009; Voelk et al., 2014). In particular, Staph. aureus GTB, a major contaminant in Swiss raw milk cheese (Hummerjohann et al., 2014), was characterized by the presence of the enterotoxin genes sea, sed, and sej, and a SNP lukE gene (lukEB; Cosandey et al., 2016). Genotype B has been found not only in Switzerland, but also in other countries of central Europe, including Italy, indicating that it is a relevant international problem in cow milk production (Cosandey et al., 2016). Regarding these aspects, the current study was carried out to compare the biofilm-forming capabilities of different genotypes of Staph. aureus dairy isolates, including Staph. aureus GTB and methicillin-resistant Staph. aureus (MRSA), because MRSA are a severe problem in the human population and have been isolated from milk, cheese, and other foodstuffs in different countries (Normanno et al., 2007; De Boer et al., 2009; Kav et al., 2011). We evaluated the ability of Staph. aureus dairy isolates to form biofilm under static and dynamic conditions and by using scanning electron microscopy. We hypothesized that biofilm formation might be more prevalent in the more contagious GTB strains compared with other genotypes (OGT).

\section{MATERIALS AND METHODS}

\section{Bacterial Isolates}

The experiment was conducted on 24 isolates (including 6 GTB strains) from milk and milk products. One isolate from poultry meat (PR 281), previously described as strong biofilm producer (Di Ciccio et al., 2015), and 3 strains from a culture collection (ATCC3556, ATCC12600, ATCC12228; American
Type Culture Collection, Manassas, VA) were included as reference strains (Table 1). Stock cultures were stored at $-80^{\circ} \mathrm{C}$, and strains were incubated for $24 \mathrm{~h}$ at $37^{\circ} \mathrm{C}$ in tryptic soy broth (TSB, BBL Becton Dickinson, Le Pont de Claix, France) before experiments.

\section{Extraction of Nucleic Acids}

A single colony of Staph. aureus was resuspended in $100 \mu \mathrm{L}$ of Tris-EDTA buffer $(10 \mathrm{~m} M$ Tris/HCl, 1 $\mathrm{m} M$ EDTA, $\mathrm{pH} 8.0$ ), incubated at $95^{\circ} \mathrm{C}$ for $10 \mathrm{~min}$, and immediately placed into ice. For PCR analysis, the lysate was diluted 1:100 in $\mathrm{H}_{2} \mathrm{O}$ and directly used for amplification.

\section{Genotyping}

Genotyping of the strains was based on PCR amplification of the 16S-23S rRNA intergenic spacer region (RS-PCR) and was performed as described by Fournier et al. (2008). Briefly, the PCR reaction mix (total volume of $25 \mu \mathrm{L}$ ) contained $1 \times$ HotStarTaq Master Mix (Qiagen AG, Hombrechtikon, Switzerland), $800 \mathrm{nmol}$ of each primer G1 and L1 (Jensen et al., 1993), and $30 \mu \mathrm{g}$ of the lysate nucleic acids. The PCR conditions were as follows: denaturation at $95^{\circ} \mathrm{C}$ for $15 \mathrm{~min}$ followed by 27 cycles of $94^{\circ} \mathrm{C}$ for $1 \mathrm{~min}, 2$-min ramp time, annealing at $55^{\circ} \mathrm{C}$ for $7 \mathrm{~min}, 2-\mathrm{min}$ ramp time, and extension for at $72^{\circ} \mathrm{C}$ for 2 min on a T-Professional thermal cycler (Biometra, Göttingen, Germany). The PCR products were analyzed by the miniaturized electrophoresis system DNA 7500 LabChip (Agilent Technologies, Basel, Switzerland). The resulting amplification patterns were interpreted according to Fournier et al. (2008), using a computer program developed in-house (Syring et al., 2012).

\section{spa Typing}

The spa typing was based on the amplification of the spacer region of the spa gene of Staph. aureus which

Table 1. Optical density (OD) at $550 \mathrm{~nm}$ and biofilm production index (BPI) of reference strains on polystyrene

\begin{tabular}{lcc}
\hline Reference strain & $\mathrm{OD}^{1}$ & $\mathrm{BPI}$ \\
\hline $\begin{array}{l}\text { Staphylococcus aureus ATCC 35556 } \\
\quad \text { (positive control, strong biofilm producer) }\end{array}$ & $0.756 \pm 0.15$ & 0.758 \\
$\begin{array}{l}\text { Staph. aureus ATCC 12600 } \\
\quad \text { (moderate biofilm producer) }\end{array}$ & $0.450 \pm 0.07$ & 0.405 \\
$\begin{array}{l}\text { Staphylococcus epidermidis ATCC 12228 } \\
\quad \text { (negative control) }\end{array}$ & $0.343 \pm 0.05$ & 0.294 \\
$\begin{array}{l}\text { Staph. aureus PR 281 } \\
\quad \text { (poultry isolate, very strong biofilm producer) }\end{array}$ & $0.979 \pm 0.255$ & 1.09 \\
${ }^{1}$ Values are expressed as OD mean \pm SD. & &
\end{tabular}


encodes staphylococcal protein A. It was performed according to the method described by Boss et al. (2016). Briefly, the PCR reaction mix (total volume of 25 $\mu \mathrm{L}$ ) contained $300 \mathrm{nmol}$ of each primer, $12.5 \mu \mathrm{L}$ of of HotStarTaq Master Mix (Qiagen AG), and $2.5 \mu \mathrm{L}$ of template DNA. The PCR cycles included a denaturation step at $95^{\circ} \mathrm{C}$ for $15 \mathrm{~min}$, followed by 37 cycles of denaturation at $94^{\circ} \mathrm{C}$ for $60 \mathrm{~s}$, annealing at 6 The $0^{\circ} \mathrm{C}$ for $60 \mathrm{~s}$, and a single extension step at $72^{\circ} \mathrm{C}$ for 10 min on a T-Professional thermal cycler (Biometra). PCR products were sent to Microsynth AG (Balgach, Switzerland) for purification and sequencing using the Sanger approach. The obtained sequences were then evaluated for corresponding spa type (t) using the Ridom server (http://www.spaserver.ridom.de/).

\section{Detection of nuc and mecA Genes}

All isolates were confirmed as MRSA by the detection of the methicillin resistance mecA gene and thermostable nuclease nuc gene. The DNA extracts were subjected to a duplex-PCR protocol for the detection of mecA and nuc (Virgin et al., 2009). A methicillinsusceptible Staph. aureus strain (ATCC29213) was used as a negative control and a MRSA strain (ATCC33591) as a positive control.

\section{Biofilm Formation Under Static Conditions}

All strains were tested in triplicate on polystyrene tissue culture plates at different temperatures $\left(37^{\circ} \mathrm{C}\right.$, $20^{\circ} \mathrm{C}$ ) and incubation times $(24,48$, and $72 \mathrm{~h}$ ) for biofilm production. For this purpose, 2 Staph. aureus and the Staph. epidermidis reference strains were used as control to define different categories of the Staph. aureus isolates to be studied. Biofilm formation, expressed as biofilm production index (BPI), was compared with reference strains: Staph. aureus ATCC35556 (strong biofilm producer; Cramton et al., 1999; Seidl et al., 2008) as positive control $\left(\mathbf{B P I}_{\mathbf{P C}}\right)$; Staph. aureus ATCC12600 (moderate biofilm producer; Di Ciccio et al., 2015) ( $\mathbf{B P I}_{\mathbf{1 2 6 0 0}}$ ); Staph. epidermidis 12228 (negative biofilm producer; Atshan et al., 2012; Lee et al., 2014) as negative control (BPI $\left.\mathbf{I}_{\mathbf{N C}}\right)$ for each isolate (Table 1). The cutoff point for biofilm production was the $\mathrm{BPI}$ value obtained by $\mathrm{BPI}_{\mathrm{NC}}$ on polystyrene (0.294). Staphylococcus aureus strains showing the ability to produce biofilms were classified as weak $\left(\mathrm{BPI}_{\mathrm{NC}} \leq\right.$ Staph. aureus $\left.\mathrm{BPI}<\mathrm{BPI}_{12600}\right)$, moderate $\left(\mathrm{BPI}_{12600} \leq\right.$ Staph. aureus $\mathrm{BPI}<\mathrm{BPI}_{\mathrm{PC}}$ ), or strong (Staph. aureus $\mathrm{BPI}$ $\geq \mathrm{BPI}_{\mathrm{PC}}$ ). Before conducting the experiments, Staph. aureus strains were activated by culturing twice in 10 $\mathrm{mL}$ of TSB (Oxoid S.p.A., Milan, Italy) at $37^{\circ} \mathrm{C}$ for 24 $\mathrm{h}$ following a previously described method (Di Ciccio et al., 2015). Cultures of Staph. aureus, from overnight tryptic soy agar (Oxoid) growth, were prepared in TSB by incubating at $37^{\circ} \mathrm{C}$. Cultures were then washed 3 times with PBS (pH 7.3, Sigma-Aldrich S.r.l., Milan, Italy) and diluted with fresh TSB to reach a concentration of about $10^{8} \mathrm{cfu} / \mathrm{mL}$, which was assessed by reading the optical density (OD) at $550 \mathrm{~nm}$ using a Varian SII Scan Cary 100 spectrophotometer (Agilent Technologies, Santa Clara, CA). Three milliliters of the standardized inoculum was then added to polystyrene tissue culture plates $\left(961 \mathrm{~mm}^{2}, 35 \mathrm{~mm}\right.$ in diameter). Samples were then incubated at $37^{\circ} \mathrm{C}$ (for $24 \mathrm{~h}$ ) and $20^{\circ} \mathrm{C}$ (for 48 or $72 \mathrm{~h}$ ). After incubation, nonadherent cells were removed by dipping each sample 3 times in sterile PBS. Samples were fixed at $60^{\circ} \mathrm{C}$ for $1 \mathrm{~h}$ and stained with $3 \mathrm{~mL}$ of $2 \%$ crystal violet solution in $95 \%$ ethanol for 15 min. After staining, samples were washed with distilled water. Negative controls underwent the same treatment, without inoculation. The quantitative analysis of biofilm production was performed by adding $3 \mathrm{~mL}$ of $33 \%$ acetic acid to destain the samples. From each sample, $200 \mu \mathrm{L}$ was transferred to a microtiter plate and the OD level of the crystal violet solution present in the destaining solution was measured at 492 nm (Victor, Perkin Elmer, Waltham, MA). All results were expressed by calculating the BPI as follows: BPI $=\left[\mathrm{OD}_{\text {mean }}\right.$ biofilm surface $\left.\left(\mathrm{mm}^{2}\right)^{-1}\right] \times 1,000$. Biofilm formation, expressed as BPI, was compared with reference strains for each isolate. Finally, all isolates were assigned to different categories based on their BPI values.

\section{Biofilm Formation Under Dynamic Conditions}

Biofilm formation under flow conditions was evaluated on 24 dairy isolates and 4 reference strains using a BioFlux 1000 microfluidic system (Fluxion Biosciences Inc., San Francisco, CA) as previously described (Moormeier et al., 2013) with some modifications. This device enables accurate control of fluid flow and permits simultaneous growth of multiple biofilms (Benoit et al., 2010). To grow biofilms in the BioFlux device, 48-well plates (Fluxion Biosciences Inc.) were used. The microfluidic channels $(70 \times 370 \mu \mathrm{m})$ were primed for 2 min with $200 \mu \mathrm{L}$ of TSB at $2.0 \mathrm{dyn} / \mathrm{cm}^{2}$ (where 1 dyn $=10^{-} 5 \mathrm{~N}$ ). After priming, the TSB was carefully removed from the outlet wells and replaced with $20 \mu \mathrm{L}$ of fresh overnight culture of Staph. aureus adjusted to reach an inoculum concentration of $10^{8} \mathrm{cfu} / \mathrm{mL}$. The channels were seeded by pumping from the outlet wells to the inlet wells at $2.0 \mathrm{dyn} / \mathrm{cm}^{2}$ for $5 \mathrm{~s}$. Cells were then allowed to attach to the surface of the channels 
for $1 \mathrm{~h}$ at $37^{\circ} \mathrm{C}$. Excess inoculum was aspirated from the outlet wells, and $1.2 \mathrm{~mL}$ of TSB was added to the inlet wells and pumped at $0.6 \mathrm{dyn} / \mathrm{cm}^{-2}$ for $17 \mathrm{~h}$. For each isolate tested, one bright-field image per channel was acquired at 5-fold magnification in 30-min intervals for a total of 35 time points $(17 \mathrm{~h})$. Images were always taken at the middle of the channel (channel numbers and arrows on the plate were used as landmarks) with a digital camera, and gain, exposure, and magnification were kept constant for all images. Every isolate was tested in biological triplicates with 2 channels for each replicate. Biofilm-forming ability was evaluated by classifying isolates into 3 main phenotypical categories: biofilm, bacterial accumulation/aggregates, and non-biofilm. The biofilm phenotype included isolates forming dense, stable aggregates of bacteria sticking to the surface of the channel over time. Bacteria forming small, diffuse aggregates or bacterial smear were classified in the bacterial accumulation/aggregates phenotype. Finally, the non-biofilm phenotype includes all isolates presenting adherent bacteria only, with no accumulation abilities or forming unstable aggregates. All phenotypic observations were made on the entire time-lapse movie. The observation of a stable biofilm structure at least once during the time course of the experiment automatically classified the isolate in the biofilm-forming category. Figure 1 illustrates the different phenotypes, and Figure 2 summarizes the classification method. The 6 replicates of each isolate were classified into 1 of the 3 phenotypic categories. For each isolate, the total number of replicates belonging to each phenotype was calculated. Based on this, a first distinction was made regarding the isolates' behavior in terms of biofilm formation under flow conditions. Isolates were subcategorized into 3 groups: (1) the consistent group, including isolates presenting the same phenotype for each replicate; (2) the dominant group, including isolates presenting a dominant phenotype observed more often than the others among the replicates, and (3) the inconsistent group, including isolates that randomly showed different phenotypes. The isolates belonging to the consistent and dominant groups were further classified according to their biofilm formation potential following the method described before. For the dominant group, the dominant phenotype was chosen. This classification method gives information about biofilm formation phenotype and its reproducibility.

\section{Scanning Electron Microscopy of Staph. aureus Biofilm}

Biofilm formation was further confirmed by scanning electron microscopy. Two isolates were selected: Staph. aureus 18 (GTB) and Staph. aureus 13 (genotype C, GTC), and biofilms were prepared as described above. The microbial cells were grown at $37^{\circ} \mathrm{C}$ for $24 \mathrm{~h}$ on polystyrene tissue plates and then washed by dipping 3 times in sterile PBS to remove nonadherent cells. Cells were fixed with $2.5 \%$ glutaraldehyde in $0.1 \mathrm{M}$ sodium cacodylate buffer ( $\mathrm{pH} 7.2$ ) for $30 \mathrm{~min}$ at room temperature and then fixed in $1 \%$ osmium tetroxide (for 1 h). Samples were then washed with $0.1 \mathrm{M}$ cacodylate buffer for $1 \mathrm{~h}$ to remove any unreacted glutaraldehyde before rinsing and dehydration. Samples were dehydrated through a series of alcohols and dried to critical point with liquid $\mathrm{CO}_{2}$ (CPD 030 Baltec, Leica Microsystems $\mathrm{GmbH}$, Wetzlar, Germany). Specimens were then sputter-coated with a gold-palladium layer using a SCD 040 coating device (Balzer Union, Liechtenstein). Samples were observed using a Zeiss DSM 950 scanning electron microscope at an accelerating voltage of 10 $\mathrm{kV}$ (Zeiss, Oberkochen, Germany). The images were processed for display using Photoshop (Adobe Systems Inc., San Jose, CA).

\section{Statistics}

All experiments were carried out in triplicate and repeated in 2 independent sets of experiments. Data are shown as mean \pm standard deviation (SD), and IBM

a)

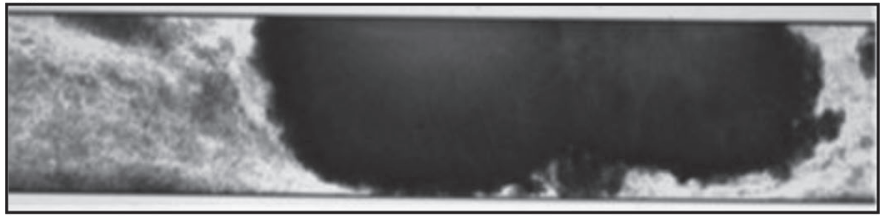

b)

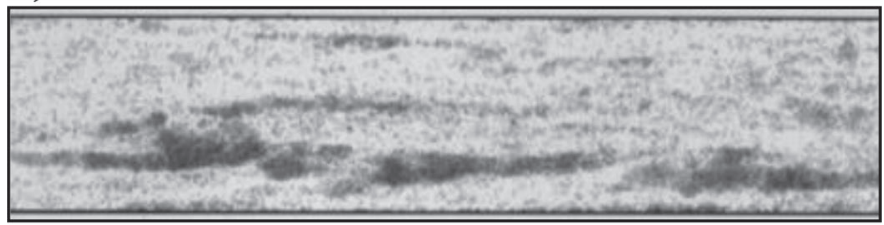

c)

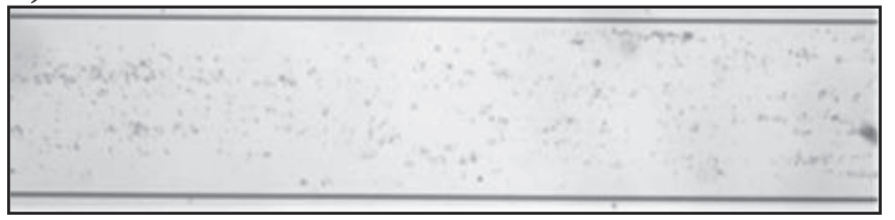

Figure 1. Different phenotypes obtained when growing Staphylococcus aureus under flow conditions (BioFlux, Fluxion Biosciences Inc., San Francisco, CA): (a) biofilm phenotype, (b) aggregates/accumulation phenotype, and (c) non-biofilm phenotype. 
SPSS Statistics 23 (IBM Corp., Armonk, NY) was used for statistical analysis. The significance of differences in biofilm formation between GTB group and OGT group was assessed by one-way ANOVA, followed by Scheffé test. Differences were considered significant when $P<$ 0.05 .

\section{RESULTS}

\section{Genotyping and spa Typing}

The Staph. aureus dairy isolates of this study were genotyped and the results are summarized in Table 2. The RS-PCR analysis revealed 11 different genotypes with 3 genotypes carrying variants, and 18 spa types were detected, including a new one. Furthermore, 9 of the chosen isolates ( 7 strains from bovine milk, 1 strain from goat milk, 1 strain from sheep milk) carried the $m e c A$ gene and were thus categorized as MRSA (Table $2)$.

\section{Biofilm Formation in the Static Model}

Differences in biofilm formation were observed between the Staph. aureus isolates tested. Figure 3 shows the ability of the 24 Staph. aureus dairy isolates and reference strains (ATCC35556, ATCC12600, ATCC12228,
PR 281), to produce biofilms in polystyrene tissue culture plates. Results are summarized in Table 3.

At $37^{\circ} \mathrm{C}(24 \mathrm{~h})$, out of 24 dairy isolates, $13(54 \%)$ did not produce biofilm, whereas $11(45.8 \%)$ were classified as weak $(\mathrm{n}=2)$, moderate $(\mathrm{n}=8)$, or strong $(\mathrm{n}=$ 1) biofilm producers, respectively. It was shown that none of the biofilm-negative strains were GTB. Among biofilm-positive strains, $6(54.5 \%)$ GTB isolates had the ability to form moderate $(\mathrm{n}=5)$ or strong $(\mathrm{n}=1$, isolate no. 18) biofilm, whereas $3(25 \%)$ MRSA isolates had the ability to form moderate $(\mathrm{n}=2)$ or weak $(\mathrm{n}=$ 1) biofilm.

At $20^{\circ} \mathrm{C}$ ( $48 \mathrm{~h}$ ), out of 24 Staph. aureus dairy isolates, $17(70.8 \%)$ strains did not produce biofilm, whereas 7 $(29.2 \%)$ were classified as weak $(\mathrm{n}=2)$, moderate (n $=4)$, or strong $(\mathrm{n}=1)$ biofilm producers, respectively. It was shown that none of the biofilm-negative (17) strains were GTB. Among the biofilm-positive strains, $6(85.7 \%)$ GTB isolates had the ability to form weak (n $=1)$, moderate $(\mathrm{n}=4)$, or strong $(\mathrm{n}=1$, isolate no. 19) biofilm, whereas 1 MRSA isolate (no. 1140) was a weak biofilm producer.

At $20^{\circ} \mathrm{C}(72 \mathrm{~h})$, out of 24 Staph. aureus dairy isolates, $17(70.8 \%)$ strains did not produce biofilm, whereas 7 $(29.2 \%)$ strains were classified as weak $(\mathrm{n}=2)$, moderate $(\mathrm{n}=4)$, or strong $(\mathrm{n}=1)$ biofilm producers. Only one MRSA strain (no. 1140) was classified as a

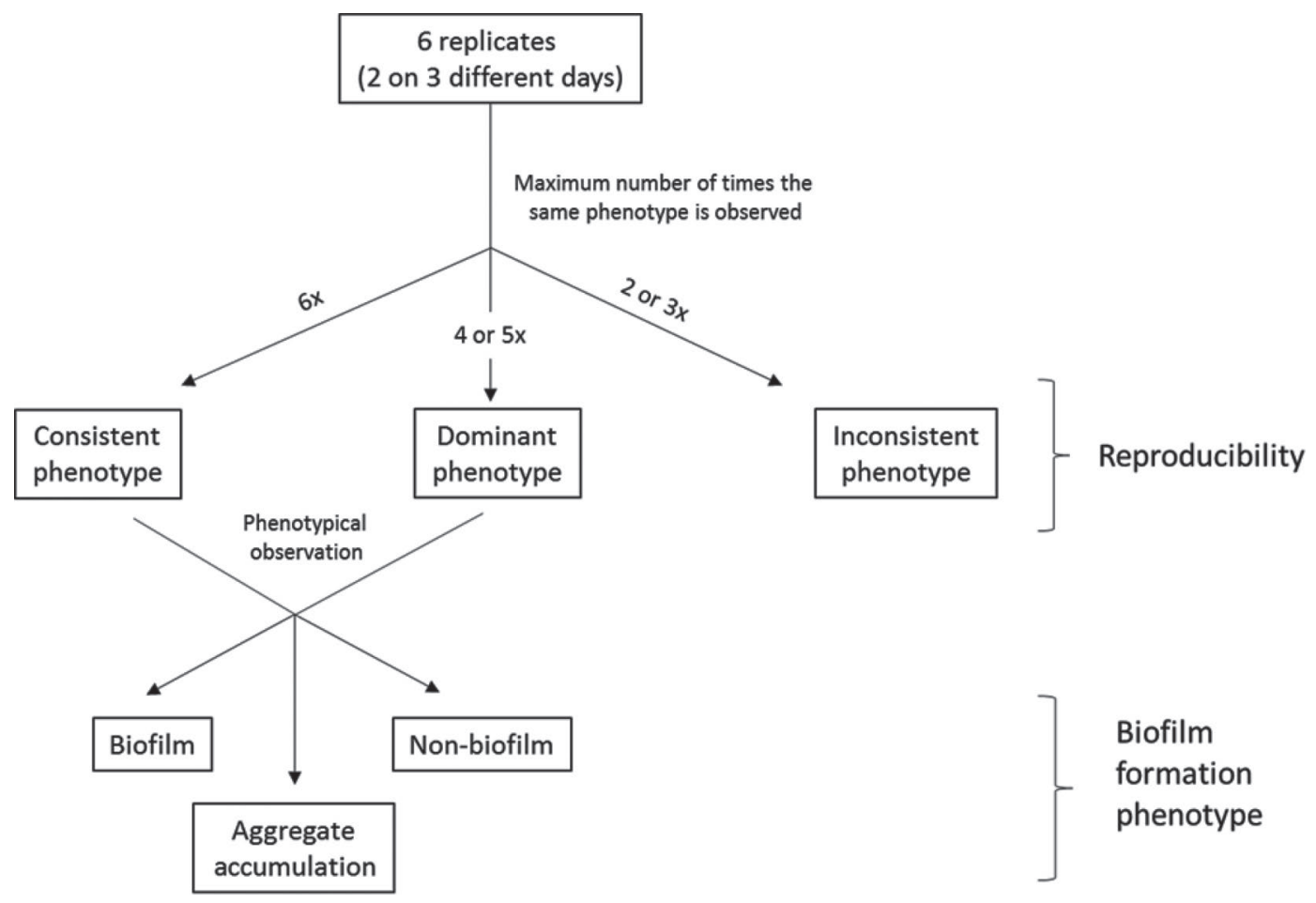

Figure 2. Classification method of the isolates analyzed under flow conditions. 
Table 2. Staphylococcus aureus dairy isolates $(\mathrm{n}=24)$ used in this study and their corresponding genotype, spa type, and methicillin resistance status

\begin{tabular}{|c|c|c|c|c|}
\hline $\begin{array}{l}\text { Isolate } \\
\text { no. }\end{array}$ & Origin (country) & Genotype & $\begin{array}{l}\text { spa } \\
\text { type }\end{array}$ & $\begin{array}{l}\mathrm{MRSA}^{1} \\
(\text { mecA PCR })\end{array}$ \\
\hline 4 & Cheese (Switzerland) & A & t2207 & Negative \\
\hline 7 & Cheese (Switzerland) & $\mathrm{I}^{\mathrm{I}}$ & $\mathrm{t} 524$ & Negative \\
\hline 8 & Mastitis milk (Switzerland) & I & $\mathrm{t} 524$ & Negative \\
\hline 12 & Mastitis milk (Switzerland) & $\mathrm{R}$ & $\mathrm{t} 267$ & Negative \\
\hline 13 & Mastitis milk (Switzerland) & $\mathrm{C}$ & t529 & Negative \\
\hline 15 & Mastitis milk (Switzerland) & $\mathrm{C}$ & t529 & Negative \\
\hline 18 & Mastitis milk (Switzerland) & B & t024 & Negative \\
\hline 19 & Cheese (Switzerland) & B & $\mathrm{t} 334$ & Negative \\
\hline 22 & Cheese (Switzerland) & B & t2953 & Negative \\
\hline 25 & Mastitis milk (Switzerland) & B & t2953 & Negative \\
\hline 27 & Mastitis milk (Switzerland) & B & t5268 & Negative \\
\hline 30 & Cheese (Switzerland) & B & t2953 & Negative \\
\hline 446 & Bovine milk (Italy) & $\mathrm{AN}^{\mathrm{I}}$ & $\mathrm{t} 174$ & Positive \\
\hline 653 & Bovine milk (Italy) & $\mathrm{R}^{\mathrm{VI}}$ & $\mathrm{t} 232$ & Negative \\
\hline 663 & Mastitis milk (Italy) & $\mathrm{F}$ & t164 & Negative \\
\hline 664 & Bovine milk (Italy) & $\mathrm{BS}^{\mathrm{II}}$ & t034 & Negative \\
\hline 852 & Bovine milk (Italy) & I & $\mathrm{t} 688$ & Positive \\
\hline 916 & Bovine milk (Italy) & $\mathrm{AQ}$ & New & Positive \\
\hline 1008 & Bovine milk (Italy) & $\mathrm{S}$ & $\mathrm{t} 524$ & Positive \\
\hline 1070 & Bovine milk (Italy) & $\mathrm{S}$ & t899 & Positive \\
\hline 1100 & Bovine milk (Italy) & $\mathrm{BN}$ & $\mathrm{t} 786$ & Positive \\
\hline 1140 & Bovine milk (Italy) & $\mathrm{AO}$ & $\mathrm{t} 1730$ & Positive \\
\hline 1234 & Goat milk (Italy) & $\mathrm{BS}^{\mathrm{III}}$ & $\mathrm{t} 1255$ & Positive \\
\hline 1242 & Sheep milk (Italy) & $\mathrm{AN}^{\mathrm{I}}$ & $\mathrm{t} 127$ & Positive \\
\hline
\end{tabular}

${ }^{1}$ Methicillin-resistant Staph. aureus.

weak biofilm producer. It was shown that none of the biofilm-negative strains (17) were GTB. Among the 7 biofilm-positive strains, $6(85.7 \%)$ isolates belonging to GTB had the ability to form weak $(\mathrm{n}=1)$, moderate ( $\mathrm{n}$
$=4)$, or strong $(\mathrm{n}=1$, isolate no. 27$)$ biofilm, respectively. Only 1 non-GTB isolate (no. 1140, MRSA) was biofilm positive (weak biofilm producer) at $20^{\circ} \mathrm{C}(48$ to $72 \mathrm{~h})$, although it was negative at $37^{\circ} \mathrm{C}(24 \mathrm{~h})$. Interest-

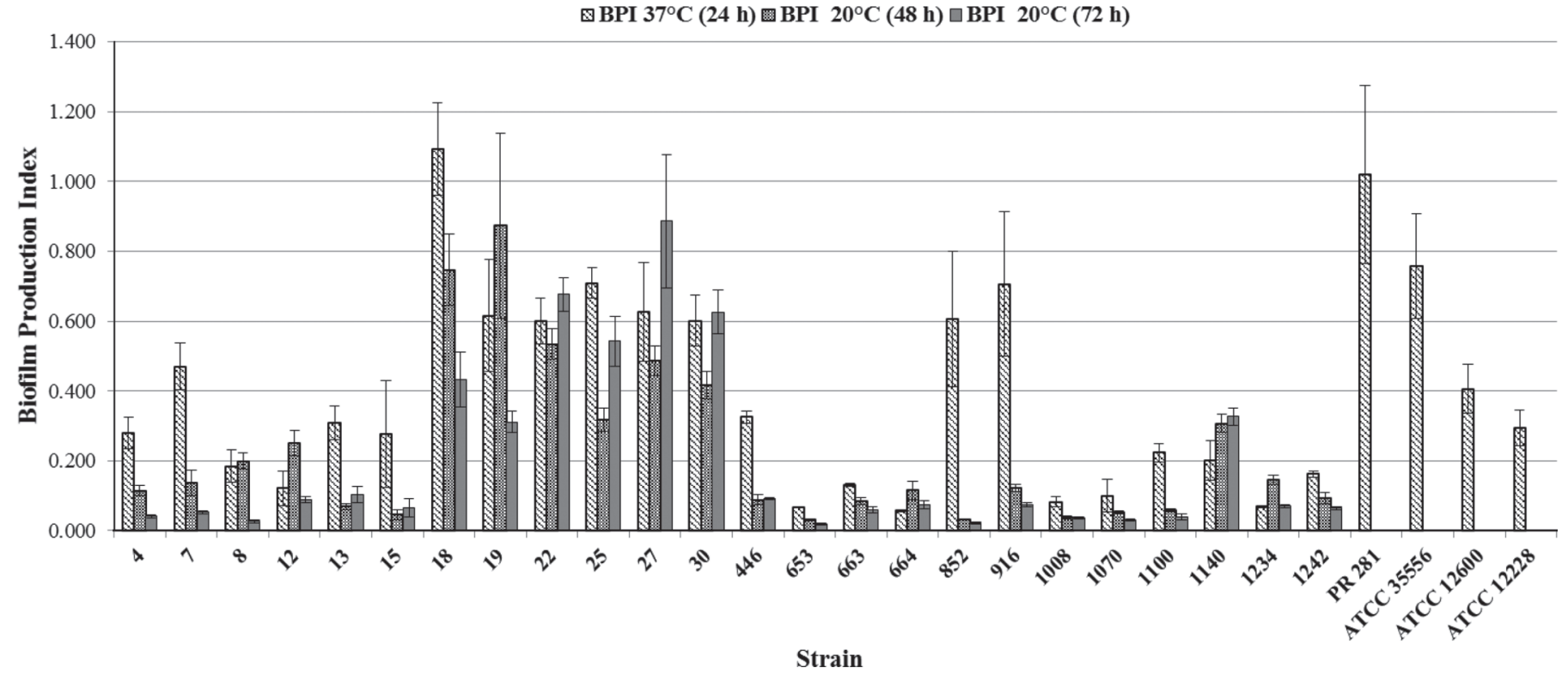

Figure 3. Biofilm formation of Staphylococcus aureus isolates at $37^{\circ} \mathrm{C}(24 \mathrm{~h})$ and $20^{\circ} \mathrm{C}(48$ and $72 \mathrm{~h})$ on polystyrene. The results, expressed as biofilm production index (BPI), are means of 3 independent experiments. Error bars represent SD. 
THIRAN ET AL.

Table 3. Biofilm formation by Staphylococcus aureus dairy isolates $(\mathrm{n}=24)$ on polystyrene (static conditions)

\begin{tabular}{|c|c|c|c|c|c|c|c|c|c|}
\hline \multirow[b]{2}{*}{ Genotype } & \multirow{2}{*}{$\frac{\text { Isolates }}{\text { No. }}$} & \multicolumn{2}{|c|}{$\begin{array}{l}\text { Biofilm } \\
\text { producer }\end{array}$} & \multicolumn{2}{|c|}{$\begin{array}{c}\text { Weak } \\
\text { producer }\end{array}$} & \multicolumn{2}{|c|}{$\begin{array}{l}\text { Moderate } \\
\text { producer }\end{array}$} & \multicolumn{2}{|c|}{$\begin{array}{l}\text { Strong } \\
\text { producer }\end{array}$} \\
\hline & & No. & $\%$ & No. & $\%$ & No. & $\%$ & No. & $\%$ \\
\hline \multicolumn{10}{|l|}{$37^{\circ} \mathrm{C}, 24 \mathrm{~h}$} \\
\hline Genotype B & 6 & 6 & 100 & 0 & 0 & 5 & 83.3 & 1 & 16.7 \\
\hline Other genotypes & 18 & 5 & 27.8 & 2 & 40.0 & 3 & 60.0 & 0 & 0 \\
\hline Total & 24 & 11 & 45.8 & 2 & 18.2 & 8 & 72.7 & 1 & 9.1 \\
\hline \multicolumn{10}{|l|}{$20^{\circ} \mathrm{C}, 48 \mathrm{~h}$} \\
\hline Genotype B & 6 & 6 & 100 & 1 & 16.7 & 4 & 66.7 & 1 & 16.7 \\
\hline Other genotypes & 18 & 1 & 5.5 & 1 & 100 & 0 & 0 & 0 & 0 \\
\hline Total & 24 & 7 & 29.2 & 2 & 28.6 & 4 & 57.1 & 1 & 14.3 \\
\hline \multicolumn{10}{|l|}{$20^{\circ} \mathrm{C}, 72 \mathrm{~h}$} \\
\hline Genotype B & 6 & 6 & 100 & 1 & 16.7 & 4 & 66.7 & 1 & 16.7 \\
\hline Other genotypes & 18 & 1 & 5.5 & 1 & 100.0 & 0 & 0 & 0 & 0 \\
\hline Total & 24 & 7 & 29.2 & 2 & 28.6 & 4 & 57.1 & 1 & 14.3 \\
\hline
\end{tabular}

ingly, the dairy isolate Staph. aureus 18 (GTB strain) showed a higher $\mathrm{BPI}$ value (at $37^{\circ} \mathrm{C}$ on polystyrene) than the poultry isolate PR 281 (no GTB strain, spa type t002, non-MRSA) that was classified as a strong biofilm producer. Finally, none of the MRSA isolates (n $=9)$ was classified as a strong biofilm producer.

Correlations between GTB strains and biofilm formation were detected by statistical analysis. The GTB strains were statistically more able $(P<0.05)$ to form biofilm than $\mathrm{OGT}$ at $37^{\circ} \mathrm{C}$ and $20^{\circ} \mathrm{C}$ (at 48 and $72 \mathrm{~h}$ of incubation).

\section{Scanning Electron Microscopy Analysis of Staph. aureus Biofilm}

Two Staph. aureus genotypes were selected for scanning electron microscopy based on their different biofilm formation on polystyrene. In particular, Staph. aureus no. 18 (GTB) showed a BPI value higher than the strong biofilm producer, PR281 (Di Ciccio et al., 2015), whereas Staph. aureus no. 13 (GTC) showed a weak biofilm-producing ability. Representative micrographs of biofilms produced by 2 analyzed isolates are shown in Figure 4. In particular, one micrograph showed Staph. aureus no. 13 forming a rudimentary biofilm consisting of sparse aggregates of cells bound by few or absent extracellular polymeric substances (Figure 4 a,b). In contrast, Staph. aureus no. 18 showed a complex 3-dimensional meshwork-like structure of cells at high density, embedded in a network of extracellular polymeric substances (Figure $4 \mathrm{c}, \mathrm{d}$ ).

\section{Biofilm Formation in the Dynamic Model}

Isolates were first classified according to the reproducibility of their biofilm formation behavior under flow conditions using the BioFlux device. Out of the 28 tested isolates (24 dairy isolates, 1 poultry isolate, and 3 reference strains), 5 (17.9\%) show a consistent phenotype: all 6 replicates of each isolate displayed the same phenotype. Sixteen $(57.19 \%)$ of them displayed a dominant phenotype, with 4 or 5 replicates out of 6 presenting the same phenotype. Finally, for 7 (25\%) of the isolates, including 2 MRSA, the phenotypes observed were not consistent from one replicate to another. Therefore, no biofilm phenotype was attributed to those isolates. The $21(75 \%)$ isolates belonging to the consistent and dominant groups were further characterized for their biofilm-forming potential. Of them, 14 isolates (66.7\%), including 5 MRSA, presented biofilm structures, whereas only $3(14.3 \%)$ showed the diffuse aggregate/accumulation phenotype and 3 (19.1\%), including 1 MRSA, were unable to accumulate and remained as adherent bacteria (Table 4).

Out of the 6 GTB isolates, 3 were non-biofilmformers (no. 19, 25, 27), 2 were biofilm formers (no. 18 and 30 ), and 1 could not be classified according to its biofilm-forming behavior because of inconsistency in reproducibility (no. 22).

\section{Comparison of Biofilm Formation Between Static and Dynamic Conditions}

The biofilm-forming potential of isolates was compared between static and dynamic conditions at $37^{\circ} \mathrm{C}$ (Table 5). Of 25 isolates, comparisons were performed for the 21 for which a phenotype could be attributed under dynamic conditions. Because the other 4 were unable to form reproducible structures under dynamic conditions, they were not included in the comparison.

Categorization under static conditions was based on 4 categories, whereas isolates were classified into 3 groups 

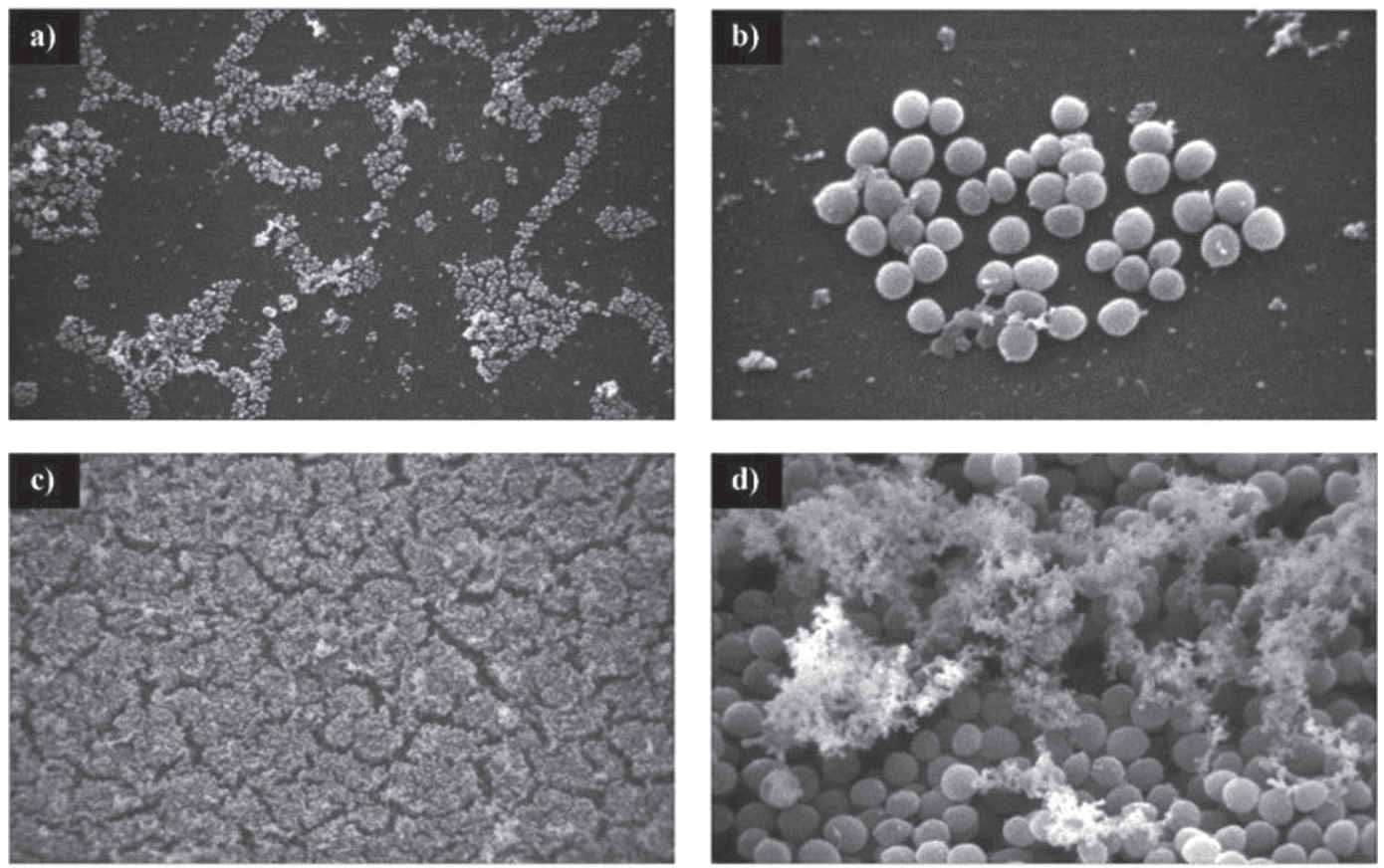

Figure 4. Scanning electron micrographs of biofilms formed by $(\mathrm{a}, \mathrm{b})$ weak biofilm producer Staphylococcus aureus isolate no. 13 (genotype C), and (c, d) strong biofilm producer Staph. aureus isolate no. 18 (genotype B). Magnification: 1,250× in panels a and c; 10,000× in panels b and $\mathrm{d}$.

under dynamic conditions. We assumed that weak and moderate formation potential under static conditions could be compared with the aggregate phenotype observed under dynamic conditions. Four isolates (19.1\%) displayed similar biofilm-forming potential under both static and dynamic conditions. One was a non-biofilmformer, 1 was a weak-to-moderate biofilm former, and 2 were strong biofilm formers. The majority of the isolates $(66.7 \%)$ tended to form more biofilm under dynamic conditions, and 6 of the MRSA belong to these category. Finally, 3 isolates $(14.3 \%)$ formed less biofilm under dynamic conditions compared with static conditions.

\section{DISCUSSION}

This is the first study on biofilm formation of Staph. aureus GTB compared with other genotypes of this species, including MRSA isolated from milk and milk products. Staphylococcus aureus isolated from bovine mastitis and cow milk is a genetically heterogeneous group (Cosandey et al., 2016). Among different genotypes, Staph. aureus GTB was found to be associated with high within-herd prevalence, indicating increased contagious and virulence potential compared with other genotypes (Graber et al., 2009; Voelk et al., 2014; van den Borne et al., 2017) and it has been described as a

Table 4. Biofilm formation potential (no., with $\%$ in parentheses; isolates in brackets ${ }^{1}$ ) of Staphylococcus aureus isolates under dynamic conditions and its reproducibility

\begin{tabular}{llll}
\hline & \multicolumn{3}{c}{ Biofilm formation potential $37^{\circ} \mathrm{C}, 17 \mathrm{~h}$, in flow cell } \\
\cline { 2 - 4 } Reproducibility & Biofilm & $\begin{array}{l}\text { Aggregate } \\
\text { accumulation }\end{array}$ & Non-biofilm \\
\hline Consistency & $4(80) ;\left[15, \mathrm{PR} 281,446^{\mathrm{M}}, 1070^{\mathrm{M}}\right]$ & $1(20) ;\left[1100^{\mathrm{M}}\right]$ & $0(0)$ \\
Dominancy & $10(62.5) ;\left[7,8,12,18^{\mathrm{B}}, 30^{\mathrm{B}}, 653,663,916^{\mathrm{M}}, 1234^{\mathrm{M}}, 1242^{\mathrm{M}}\right]$ & $2(12.5) ;[13,664]$ & $4(25) ;\left[19^{\mathrm{B}}, 25^{\mathrm{B}}, 27^{\mathrm{B}}, 1008^{\mathrm{M}}\right]$ \\
Inconsistency & $7(25) ;\left[4,22^{\mathrm{B}}, 852^{\mathrm{M}}, 1140^{\mathrm{M}}, \mathrm{ATCC} 12600\right.$, ATCC29213, ATCC35556] & & $4(19.1)$ \\
$\begin{array}{l}\text { Total, number } \\
(\%)\end{array}$ & $14(66.7)$ & $3(14.3)$ & \\
\hline
\end{tabular}

\footnotetext{
${ }^{1}$ Superscript $\mathrm{M}=$ methicillin-resistant isolate $($ mecA-PCR + ); superscript $\mathrm{B}=$ genotype $\mathrm{B}$.
} 
Table 5. Comparison between biofilm formation under static and dynamic conditions in tryptic soy broth at $37^{\circ} \mathrm{C}^{1}$

\begin{tabular}{llll}
\hline $\begin{array}{l}\text { Static } \\
\text { conditions }\end{array}$ & $\begin{array}{l}\text { Dynamic } \\
\text { conditions }\end{array}$ & Staphylococcus aureus isolates ${ }^{2}$ & $\begin{array}{l}\text { Comparison static vs. dynamic } \\
\text { conditions: no. (\%) }\end{array}$ \\
\hline- & - & $1008^{\mathrm{M}}$ & Similar biofilm formation potential: 4 (19.1) \\
+ & + & 13 & \\
++ & ++ & $18^{\mathrm{B}}, \mathrm{PR} 281$ & \\
- & + & $664,1100^{\mathrm{M}}$ & Stronger biofilm formation under dynamic \\
- & ++ & $8,12,15,653,663,1070^{\mathrm{M}}, 1234^{\mathrm{M}}, 1242^{\mathrm{M}}$ & conditions: $14(66.7)$ \\
+ & ++ & $7,30^{\mathrm{B}}, 446^{\mathrm{M}}, 916^{\mathrm{M}}$ & \\
+ & - & $19^{\mathrm{B}}, 25^{\mathrm{B}}, 27^{\mathrm{B}}$ & Stronger biofilm formation under static \\
& & & conditions: 3 (14.3) \\
- & $/$ & 4,1140 & No comparison possible: 4 (19.1) \\
\hline
\end{tabular}

${ }^{1}$ During static conditions, Staph. aureus biofilms were grown on polystyrene surfaces for $24 \mathrm{~h}$; during dynamic conditions, they were grown in flow cells on glass surfaces for $17 \mathrm{~h} .++=$ strong biofilm formation, $+=$ weak to moderate and bacterial aggregates/accumulation, $-=$ no biofilm formation, / = inconsistent biofilm formation.

${ }^{2}$ Superscript $\mathrm{M}=$ methicillin-resistant isolate $($ mecA-PCR + ); superscript $\mathrm{B}=$ genotype $\mathrm{B}$.

major contaminant in Swiss raw milk cheeses (Hummerjohann et al., 2014).

Regarding these aspects, this study was carried out with the aim of evaluating the ability of Staph. aureus isolated from milk and milk products to form biofilm under static and dynamic conditions. Additionally, our aim was to test whether Staph. aureus GTB isolates were more likely to be biofilm producers than other Staph. aureus genotypes. The results of biofilm formation in the static model support this hypothesis, as GTB isolates produced significantly more biofilms than other genotypes under the several conditions tested. Furthermore, 1 GTB isolate was seen to be a better biofilm producer than GTC in the scanning electron microscopy analysis. Interestingly, the dairy isolate Staph. aureus 18 (GTB strain) showed a higher BPI value than the poultry isolate Staph. aureus PR 281 (not GTB), that was described as a strong biofilm producer by Di Ciccio et al. (2015). Further studies are needed to evaluate the contribution of biofilm formation to the persistence of Staph. aureus GTB in dairy, which has been observed for cheese-making facilities with duration of up to 27 wk (Hummerjohann et al., 2014).

Although the study presented here is one of the few reports on Staph. aureus spa types and biofilm formation in a dairy environment, it is generally believed that strong biofilm formation is linked to certain genetic lineages, as found by several clinical studies (Croes et al., 2009; Naicker et al., 2016). Application of methods on the genomics, transcriptomics, and proteomics level of those different lineages could probably explain these observed phenotypes in the future.

Furthermore, because not all subtypes of Staph. aureus are distributed equally all over the world, applica- tion of subtyping is an important tool for local dairies. Veh et al. (2015) were able to characterize genotypic and phenotypic Staph. aureus causing persistent and nonpersistent subclinical bovine IMI in Canada. That study, where no GTB was detected, reported that t529 and t267 were the subtypes with the lowest biofilm production, which was confirmed by our study. This indicates the need for further regional studies on biofilm formation, including those genotypes that predominate in the milk production of certain specific regions.

Regarding the typing of our isolates, genotypes B, C, F, I, and R, are typically associated with bovine isolates and are the more frequently encountered genotypes when typing European Staph. aureus isolated from cow milk (Cosandey et al., 2016). In general, no correlation between genotype and spa type could be established except for spa type t529, which seemed to be associated with GTC, and t2953, which is the most frequently observed spa type of Staph. aureus GTB (Hummerjohann et al., 2014; Boss et al., 2016). In contrast, spa type t524 has been associated with 3 different genotypes. Several spa types described in this study (t524, t127, t267, t529, t204, t295) have previously been associated with bovine isolates in other countries (Hasman et al., 2010; Hwang et al., 2010; Sakwinska et al., 2011; Mitra et al., 2013; Boss et al., 2016).

Another aspect to note in our study was the presence of MRSA among our dairy isolates. Regarding their corresponding spa types, 2 isolates (t127 and t174) were of human origin (Grundmann et al., 2010; Lozano et al., 2011). Many reports have identified MRSA in bovine mastitis cases or in dairy products in several countries including Italy (Normanno et al., 2007; Kav et al., 2011; Kamal et al., 2013). In our study, 9 dairy isolates were 
classified as MRSA. Among them, 55.5\% form biofilms under dynamic conditions and $44.4 \%$ displayed weak to moderate biofilm-forming abilities under static conditions. Although the exact mechanisms and process of biofilm formation in MRSA are poorly understood, 2 studies performed by the same research group suggested that penicillin binding protein $2 \mathrm{a}(\mathrm{PBP} 2 \mathrm{a})$ is also an important factor in biofilm accumulation (Pozzi et al., 2012; Rudkin et al., 2012). Other studies looked at dairy MRSA isolates and highlighted their high biofilmforming potential. Bardiau et al. (2013) found that all MRSA isolated from bovine mastitis in Belgium were biofilm formers. Prenafeta et al. (2014) described a 50\% prevalence of biofilm formation among MRSA isolated in bulk tank milk in Great Britain. It is well known that MRSA detected from milk and dairy products can be staphylococcal enterotoxin producers (Normanno et al., 2007; Parisi et al., 2016). To date, the contribution of the contaminated environment to the spread of antimicrobial resistant microorganisms is not well understood. However, the biofilm-forming ability of MRSA that are potentially staphylococcal enterotoxin producers should be of concern for food safety, because they may colonize and spread in the dairy industry environment, leading to food contamination. Despite the importance of the $i c a$ gene locus in biofilm development, biofilms can occur in an ica-independent fashion. In a preliminary study, we discovered the presence of the $i c a A$ gene in some of the genomes of different genotypes. However, as the presence or absence of this gene is not correlated with a certain biofilm formation phenotype (H. U. Graber, unpublished data), further study on expression of the different genes is needed.

With regard to this, ica-independent biofilms appear to be the most important bacterial films produced by MRSA isolates (Vasudevan et al., 2003; Cucarella et al., 2004; O'Neill et al., 2007). The ability of dairyisolated multidrug resistant bacteria to form biofilms in food processing facilities is of great concern for food safety. First, it contributes to the spread of antibiotic resistance along the food chain. Because biofilms confer an intrinsic resistance to disinfection methods, they are very difficult to eliminate and contribute to bacterial persistence in food processing facilities. Moreover, the proximity of cells within biofilms favors horizontal gene transfer and risk for resistance transmission to pathogenic bacteria, leading to potential further treatment failure (Verraes et al., 2013).

When looking at the results of biofilm formation under dynamic conditions, the pronounced biofilmforming potential of Staph. aureus GTB was not that obvious. Indeed, only half of the GTB isolates show biofilm structures and it was impossible to assign a biofilm formation potential for 1 isolate because of inconsistency in the reproducibility. However, the strong biofilm formation potential of Staph. aureus GTB isolates under static conditions reveals that this genotype possesses the genetic information necessary to form biofilms under certain conditions.

Only one strain (no. 1140, MRSA) was biofilm positive (weak biofilm producer) at $20^{\circ} \mathrm{C}(48$ to $72 \mathrm{~h}$ ), although it was negative for biofilm formation at $37^{\circ} \mathrm{C}$ (24 h). Rode et al. (2007), in contrast, noted the highest attachment capacity in Staph. aureus on polystyrene at suboptimal growth temperatures $\left(20,25\right.$, and $\left.30^{\circ} \mathrm{C}\right)$.

Comparison of our data with reports from Pagedar et al. (2010), da Silva Meira et al. (2012), Lee at al. (2014) and Di Ciccio et al. (2015) on Staph. aureus dairy and other food isolates is rather limited because of the application of different methods of subtyping (if applied at all) and measurement or categorization of biofilm formation. The comparison between biofilm formation under static and dynamic conditions is even more complicated. In clinical isolates, only $19 \%$ of the isolates behaved similarly under both static and dynamic conditions (Vanhommerig et al., 2014), which is similar to our results (Table 5). Factors including incubation time, growth surface, and nutrients are thought to influence biofilm formation in staphylococci measured by static or dynamic model assays (Stepanović et al., 2001; Vanhommerig et al., 2014; Van Kerckhoven et al., 2016). Furthermore, we have recently shown similar results on biofilm formation of $E$. coli dairy isolates, noting a lack of correlation between static and dynamic conditions (Marti et al., 2017). From our results, we cannot conclude that differences observed in terms of biofilm formation are due only to the growth under flow conditions because the growth surface was not the same (polystyrene for the static model; glass in the dynamic model), which can influence the adhesion process. Moreover, growth time was slightly different, with a longer incubation time under static conditions.

Finally, the evaluation process differed and could influence the conclusions. For the dynamic conditions, we had a time-lapse overview, whereas biofilm formation under static conditions was evaluated based on an end point state. Despite these differences, the fact that biofilm formation was observed in either condition indicates that the isolate possesses the genetic information necessary for biofilm formation. Further studies are needed to characterize the underlying mechanism of these phenotypes and to evaluate which of the different assays used for the measurement of biofilm formation best mimics the "real" situation in the dairy environment. Scanning electronic microscopy could be used as a semiquantitative technique, because it allows the ob- 
servation of bacteria-surface interactions. Thus, in this study, scanning electron microscopy was used to confirm the biofilm formation of 2 differently categorized strains, and the images confirmed the results obtained from static biofilm assay, showing a strong difference in biofilm formation of 2 different genotypes.

\section{CONCLUSIONS}

All Staph. aureus GTB dairy isolates used in the present study showed significantly higher biofilm formation on polystyrene when exposed to different environmental conditions compared with most of the other genotypes, including MRSA. Under dynamic conditions, the ability of GTB strains to be good biofilm formers was not observed in all cases, emphasizing the importance of growth conditions for the expression of biofilm-related genes. In summary, the results of this study expand our knowledge of different Staph. aureus subtypes from the dairy field and show the benefit of genotyping when biofilm formation is studied.

\section{ACKNOWLEDGMENTS}

A. Ianieri, J. Hummerjohann, and P. A. Di Ciccio were members of the EU COST Action FA1202 "A European Network for Mitigating Bacterial Colonisation and Persistence on Foods and Food Processing Environments" (http://www.bacfoodnet.org/) and this action is acknowledged for a travel grant to P. A. Di Ciccio. We thank F. Ravanetti (Department of Veterinary Science, University of Parma, Italy) for her technical assistance. E. Thiran was supported by the Agroscope research programme REDYMO (Berne, Switzerland).

\section{REFERENCES}

Atshan, S. S., M. N. Shamsudin, L. T. Thian Lung, Z. Sekawi, E. Ghaznavi-Rad, and C. Pei. 2012. Comparative characterisation of genotypically different clones of MRSA in the production of biofilms. J. Biomed. Biotechnol. 2012:417247. https://doi.org/10 $.1155 / 2012 / 417247$.

Bardiau, M., K. Yamazaki, J. N. Duprez, B. Taminiau, J. G. Mainil, and I. Ote. 2013. Genotypic and phenotypic characterization of methicillin-resistant Staphylococcus aureus (MRSA) isolated from milk of bovine mastitis. Lett. Appl. Microbiol. 57:181-186.

Benoit, M. R., C. G. Conant, C. Ionescu-Zanetti, M. Schwartz, and A. Matin. 2010. New device for high-throughput viability screening of flow biofilms. Appl. Environ. Microbiol. 76:4136-4142. https://doi .org/10.1128/AEM.03065-09.

Boss, R., A. Cosandey, M. Luini, K. Artursson, M. Bardiau, F. Breitenwieser, E. Hehenberger, T. Lam, M. Mansfeld, A. Michel, G. Mösslacher, J. Naskova, S. Nelson, O. Podpečan, A. Raemy, E. Ryan, O. Salat, P. Zangerl, A. Steiner, and H. U. Graber. 2016. Bovine Staphylococcus aureus: Subtyping, evolution, and zoonotic transfer. J. Dairy Sci. 99:515-528. https://doi.org/10.3168/jds .2015-9589.

Cosandey, A., R. Boss, M. Luini, K. Artursson, M. Bardiau, F. Breitenwieser, E. Hehenberger, T. Lam, M. Mansfeld, A. Michel, G.
Mösslacher, J. Naskova, S. Nelson, O. Podpečan, A. Raemy, E. Ryan, O. Salat, P. Zangerl, A. Steiner, and H. U. Graber. 2016. Staphylococcus aureus genotype B and other genotypes isolated from cow milk in European countries. J. Dairy Sci. 99:529-540. https://doi.org/10.3168/jds.2015-9587.

Costerton, J. W., P. S. Stewart, and E. P. Greenberg. 1999. Bacterial biofilms: A common cause of persistent infections. Science 284:1318-1322. https://doi.org/10.1126/science.284.5418.1318.

Cramton, S. E., C. Gerke, N. F. Schnell, W. W. Nichols, and F. Götz. 1999. The intercellular adhesion (ica) locus is present in Staphylococcus aureus and is required for biofilm formation. Infect. Immun. 67:5427-5433.

Croes, S., R. H. Deurenberg, M. L. Boumans, P. S. Beisser, C. Neef, and E. E. Stobberingh. 2009. Staphylococcus aureus biofilm formation at the physiologic glucose concentration depends on the $S$ aureus lineage. BMC Microbiol. 9:229. https://doi.org/10.1186/ 1471-2180-9-229.

Cucarella, C., M. A. Tormo, C. Ubeda, M. P. Trotonda, M. Monzon, C. Peris, B. Amorena, I. Lasa, and J. R. Penades. 2004. Role of biofilm-associated protein Bap in the pathogenesis of bovine Staphylococcus aureus. Infect. Immun. 72:2177-2185.

da Silva Meira, Q. G., I. de Medeiros Barbosa, A. J. Alves Aguiar Athayde, J. P. de Siqueira-Júnior, and E. L. de Souza. 2012. Influence of temperature and surface kind on biofilm formation by Staphylococcus aureus from food-contact surfaces and sensitivity to sanitizers. Food Contr. 25:469-475. https://doi.org/10.1016/j foodcont.2011.11.030.

de Boer, E., J. T. Zwartkruis-Nahuis, B. Wit, X. W. Huijsdens, A. J. de Neeling, T. Bosch, R. A. van Oosterom, A. Vila, and A. E. Heuvelink. 2009. Prevalence of methicillin-resistant Staphylococcus aureus in meat. Int. J. Food Microbiol. 134:52-56.

De Buyser, M. L., B. Dufour, M. Maire, and V. Lafarge. 2001. Implication of milk and milk products in food-borne diseases in France and in different industrialised countries. Int. J. Food Microbiol. 67:1-17.

de Souza, E. L., Q. G. S. Meira, I. de M. Barbosa, A. J. A. A. Athayde, M. L. da Conceição, and J. P. de Siqueira. 2014. Biofilm formation by Staphylococcus aureus from food contact surfaces in a meatbased broth and sensitivity to sanitizers. Braz. J. Microbiol. 45:6775. https://doi.org/10.1590/S1517-83822014000100010.

Di Ciccio, P., A. Vergara, A. R. Festino, D. Paludi, E. Zanardi, S. Ghidini, and A. Ianieri. 2015. Biofilm formation by Staphylococcus aureus on food contact surfaces: Relationship with temperature and cell surface hydrophobicity. Food Contr. 50:930-936. https:// doi.org/10.1016/j.foodcont.2014.10.048.

Donlan, R. M., and J. W. Costerton. 2002. Biofilms: Survival mechanisms of clinically relevant microorganisms. Clin. Microbiol. Rev. 15:167-193. https://doi.org/10.1128/CMR.15.2.167-193.2002.

Fournier, C., P. Kuhnert, J. Frey, R. Miserez, M. Kirchhofer, T. Kaufmann, A. Steiner, and H. U. Graber. 2008. Bovine Staphylococcus aureus: Association of virulence genes, genotypes and clinical outcome. Res. Vet. Sci. 85:439-448.

Graber, H. U., J. Naskova, E. Studer, T. Kaufmann, M. Kirchhofer, M. Brechbühl, W. Schaeren, A. Steiner, and C. Fournier. 2009. Mastitis-related subtypes of bovine Staphylococcus aureus are characterized by different clinical properties. J. Dairy Sci. 92:1442-1451. https://doi.org/10.3168/jds.2008-1430.

Grundmann, H., D. M. Aanensen, C. C. van den Wijngaard, B. G Spratt, D. Harmsen, and A. W. Friedrich. 2010. Geographic distribution of Staphylococcus aureus causing invasive infections in Europe: A molecular-epidemiological analysis. PLoS Med. 12:e1000215.

Hasman, H., A. Moodley, L. Guardabassi, M. Stegger, R. L. Skov, and F. M. Aarestrup. 2010. spa type distribution in Staphylococcus aureus originating from pigs, cattle and poultry. Vet. Microbiol. 141:326-331. https://doi.org/10.1016/j.vetmic.2009.09.025.

Hennekinne, J. A., M. L. De Buyser, and S. Dragacci. 2012. Staphylococcus aureus and its food poisoning toxins: Characterization and outbreak investigation. FEMS Microbiol. Rev. 36:815-836.

Hummerjohann, J., J. Naskova, A. Baumgartner, and H. U. Graber 2014. Enterotoxin-producing Staphylococcus aureus genotype B 
as a major contaminant in Swiss raw milk cheese. J. Dairy Sci. 97:1305-1312. https://doi.org/10.3168/jds.2013-7643.

Hwang, S. Y., Y. K. Park, H. C. Koo, and Y. H. Park. 2010. spa typing and enterotoxin gene profile of Staphylococcus aureus isolated from bovine raw milk in Korea. J. Vet. Sci. 11:125-131. https://doi.org/ 10.4142/jvs.2010.11.2.125.

Jensen, M. A., J. A. Webster, and N. Straus. 1993. Rapid identification of bacteria on the basis of polymerase chain reaction-amplified ribosomal DNA spacer polymorphisms. Appl. Environ. Microbiol. 59:945-952.

Kamal, R. M., A. Mohamed, F. A. Bayoumi Salah, and E. A. Abd. 2013. MRSA detection in raw milk, some dairy products and hands of dairy workers in Egypt, a mini-survey. Food Contr. 33:49-53.

Kav, K., R. Col, and M. Ardic. 2011. Characterization of Staphylococcus aureus isolates from white-brined Urfa cheese. J. Food Prot. 74:1788-1796.

Lee, S. H. I., B. L. C. Mangolin, J. L. Gonçalves, D. V. Neeff, M. P. Silva, A. G. Cruz, and C. A. F. Oliveira. 2014. Biofilm-producing ability of Staphylococcus aureus isolates from Brazilian dairy farms. J. Dairy Sci. 97:1812-1816. https://doi.org/10.3168/jds .2013-7387.

Lozano, C., C. Aspiroz, J. J. Lasarte, E. Gómez-Sanz, M. Zarazaga, and C. Torres. 2011. Dynamic of nasal colonization by methicillinresistant Staphylococcus aureus ST398 and ST1 after mupirocin treatment in a family in close contact with pigs. Comp. Immunol. Microbiol. Infect. Dis. 34:e1-7.

Marti, R., M. Schmid, S. Kulli, K. Schneeberger, J. Naskova, S. Knøchel, C. H. Ahrens, and J. Hummerjohann. 2017. Biofilm formation potential of heat resistant Escherichia coli dairy isolates and complete genome of MDR heat resistant strain FAM21845. Appl. Environ. Microbiol. 83:e00628-17. https://doi.org/10.1128/ AEM.00628-17.

Mitra, S. D., D. Velu, M. Bhuvana, N. Krithiga, A. Banerjee, R. Shome, H. Rahman, S. K. Ghosh, and B. R. Shome. 2013. Staphylococcus aureus spa type t267, clonal ancestor of bovine subclinical mastitis in India. J. Appl. Microbiol. 114:1604-1615. https://doi .org/10.1111/jam.12186

Moormeier, D. E., J. L. Endres, E. E. Mann, M. R. Sadykov, A. R. Horswill, K. C. Rice, P. D. Fey, and K. W. Bayles. 2013. Use of microfluidic technology to analyze gene expression during Staphylococcus aureus biofilm formation reveals distinct physiological niches. Appl. Environ. Microbiol. 79:3413-3424. https://doi.org/ 10.1128/AEM.00395-13.

Naicker, P. R., K. Karayem, H. G. Hoek, J. Harvey, and E. Wasserman. 2016. Biofilm formation in invasive Staphylococcus aureus isolates is associated with the clonal lineage. Microb. Pathog. 90:41-49. https://doi.org/10.1016/j.micpath.2015.10.023.

Normanno, G., M. Corrente, G. La Salandra, A. Dambrosio, N. C Quaglia, A. Parisi, G. Greco, A. L. Bellacicco, S. Virgilio, and G. V. Celano. 2007. Methicillin-resistant Staphylococcus aureus (MRSA) in foods of animal origin product in Italy. Int. J. Food Microbiol. 117:219-222.

O'Neill, E., C. Pozzi, P. Houston, D. Smyth, H. Humphreys, D. A. Robinson, and J. P. O'Gara. 2007. Association between methicillin susceptibility and biofilm regulation in Staphylococcus aureus isolates from device-related infections. J. Clin. Microbiol. 45:13791388.

Oliver, S. P., K. J. Boor, S. C. Murphy, and S. E. Murinda. 2009. Food safety hazards associated with consumption of raw milk. Foodborne Pathog. Dis. 6:793-806. https://doi.org/10.1089/fpd.2009 .0302 .

Oniciuc, E. A., N. Cerca, and A. I. Nicolau. 2016. Compositional analysis of biofilms formed by Staphylococcus aureus isolated from food sources. Front. Microbiol. 7:390. https://doi.org/10.3389/fmicb 2016.00390

Pagedar, A., J. Singh, and V. K. Batish. 2010. Surface hydrophobicity, nutritional contents affect Staphylococcus aureus biofilms and temperature influences its survival in preformed biofilms. J. Basic Microbiol. 50: https://doi.org/10.1002/jobm.201000034.

Parisi, A., M. Caruso, G. Normanno, L. Latorre, R. Sottili, A. Miccolupo, R. Fraccalvieri, and G. Santagada. 2016. Prevalence, antimi- crobial susceptibility and molecular typing of Methicillin-Resistant Staphylococcus aureus (MRSA) in bulk tank milk from southern Italy. Food Microbiol. 58:36-42.

Pozzi, C., E. M. Waters, J. K. Rudkin, C. R. Schaeffer, A. J. Lohan, P. Tong, B. J. Loftus, G. B. Pier, P. D. Fey, R. C. Massey, and J. P. O'Gara. 2012. Methicillin resistance alters the biofilm phenotype and attenuates virulence in Staphylococcus aureus device-associated infections. PLoS Pathog. 8:e1002626.

Prenafeta, A., M. Sitja, M. A. Holmes, and G. K. Paterson. 2014. Short communication: Biofilm production characterization of mecA and mecC methicillin-resistant Staphylococcus aureus isolated from bovine milk in Great Britain. J. Dairy Sci. 97:4838-4841.

Rode, T. M., S. Langsrud, A. Holck, and T. Møretrø. 2007. Different patterns of biofilm formation in Staphylococcus aureus under food-related stress conditions. Int. J. Food Microbiol. 116:372-383. https://doi.org/10.1016/j.ijfoodmicro.2007.02.017.

Rudkin, J. K., A. M. Edwards, M. G. Bowden, E. L. Brown, C. Pozzi, E. M. Waters, W. C. Chan, P. Williams, J. P. O'Gara, and R. C. Massey. 2012. Methicillin resistance reduces the virulence of healthcare-associated methicillin-resistant Staphylococcus aureus by interfering with the agr quorum sensing system. J. Infect. Dis. 205:798-806.

Sakwinska, O., D. Morisset, J. Y. Madec, A. Waldvogel, P. Moreillon, and M. Haenni. 2011. Link between genotype and antimicrobial resistance in bovine mastitis-related Staphylococcus aureus strains, determined by comparing Swiss and French isolates from the Rhine valley. Appl. Environ. Microbiol. 77:3428-3432. https:// doi.org/10.1128/AEM.02468-10.

Santos, V. M., H. B. Martins, I. S. Rezende, M. S. Barbosa, E. F. Andrade, S. G. Souza, G. B. Campos, P. S. Oliveira, D. S. Sousa, D. C. C. Da Silva, A. T. Amorim, J. Timenetsky, M. P. Cruz, R. Yatsuda, and L. M. Marques. 2014. Virulence factor profile of Staphylococcus aureus isolated from bovine milk from Brazil. Food Nutr. Sci. 5:1496-1505. https://doi.org/10.4236/fns.2014.515162.

Seidl, K., C. Goerke, C. Wolz, D. Mack, B. Berger-Bächi, and M. Bischoff. 2008. Staphylococcus aureus CcpA affects biofilm formation. Infect. Immun. 76:2044-2050. https://doi.org/10.1128/IAI $.00035-08$.

Silva, N. C. C., F. F. Guimarães, M. P. Manzi, P. E. Budri, E. GómezSanz, D. Benito, H. Langoni, V. L. M. Rall, and C. Torres. 2013. Molecular characterization and clonal diversity of methicillinsusceptible Staphylococcus aureus in milk of cows with mastitis in Brazil. J. Dairy Sci. 96:6856-6862. https://doi.org/10.3168/jds .2013-6719.

Song, M., Q. Li, Y. Zhang, J. Song, X. Shi, and C. Shi. 2016. Biofilm formation and antibiotic resistance pattern of dominant Staphylococcus aureus clonal lineages in China. J. Food Saf. https://doi .org $/ 10.1111 /$ jfs. 12304

Stepanović, S., D. Vukovic, P. Jezek, M. Pavlovic, and M. Svabic-Vlahovic. 2001. Influence of dynamic conditions on biofilm formation by staphylococci. Eur. J. Clin. Microbiol. Infect. Dis. 20:502-504.

Syring, C., R. Boss, M. Reist, M. Bodmer, J. Hummerjohann, P. Gehrig, and H. U. Graber. 2012. Bovine mastitis: The diagnostic properties of a PCR-based assay to monitor the Staphylococcus aureus genotype B status of a herd, using bulk tank milk. J. Dairy Sci. 95:3674-3682. https://doi.org/10.3168/jds.2011-4968.

Tang, J., J. Chen, J. Liu, R. Zhang, R. Yang, and L. Chen. 2012. Effects of different cultivation conditions on Staphylococcus aureus biofilm formation and diversity of adhesin genes. J. Food Saf. 32:210-218. https://doi.org/10.1111/j.1745-4565.2012.00370.x.

van den Borne, B. H., H. U. Graber, V. Voelk, C. Sartori, A. Steiner, M. C. Haerdi-Landerer, and M. Bodmer. 2017. A longitudinal study on transmission of Staphylococcus aureus genotype B in Swiss communal dairy herds. Prev. Vet. Med. 136:65-68. https:// doi.org/10.1016/j.prevetmed.2016.11.008.

Van Kerckhoven, M., A. Hotterbeekx, E. Lanckacker, P. Moons, C. Lammens, M. Kerstens, M. Ieven, P. Delputte, P. G. Jorens, S Malhotra-Kumar, H. Goossens, L. Maes, and P. Cos. 2016. Characterizing the in vitro biofilm phenotype of Staphylococcus epidermidis isolates from central venous catheters. J. Microbiol. Methods 127:95-101. https://doi.org/10.1016/j.mimet.2016.05.009. 
Vanhommerig, E., P. Moons, D. Pirici, C. Lammens, J. P. Hernalsteens, H. De Greve, S. Kumar-Singh, H. Goossens, and S. Malhotra-Kumar. 2014. Comparison of biofilm formation between major clonal lineages of methicillin resistant Staphylococcus aureus. PLoS One 9:e104561. https://doi.org/10.1371/journal.pone.0104561.

Vasudevan, P., M. K. M. Nair, T. Annamalai, and K. S. Venkitanarayanan. 2003. Phenotypic and genotypic characterization of bovine mastitis isolates of Staphylococcus aureus for biofilm formation. Vet. Microbiol. 92:179-185.

Veh, K. A., R. C. Klein, C. Ster, G. Keefe, P. Lacasse, D. Scholl, J. P. Roy, D. Haine, S. Dufour, B. G. Talbot, A. O. Ribon, and F. Malouin. 2015. Genotypic and phenotypic characterization of Staphylococcus aureus causing persistent and nonpersistent subclinical bovine intramammary infections during lactation or the dry period. J. Dairy Sci. 98:155-168. https://doi.org/10.3168/jds .2014-8044.

Verraes, C., S. Van Boxstael, E. Van Meervenne, E. V. Coillie, P. Butaye, B. Catry, M. A. de Schaetzen, X. Van Huffel, H. Imberechts,
K. Dierick, G. Daube, C. Saegerman, J. De Block, J. Dewulf, and L. Herman. 2013. Antimicrobial resistance in the food chain: A review. Int. J. Environ. Res. Public Health 10:2643-2669.

Virgin, J. E., T. M. Van Slyke, J. E. Lombard, and R. N. Zadoks. 2009. Short communication: Methicillin-resistant Staphylococcus aureus detection in US bulk tank milk. J. Dairy Sci. 92:4988-4991.

Voelk, V., H. U. Graber, B. H. P. van den Borne, C. Sartori, A. Steiner, M. Bodmer, and M. C. Haerdi-Landerer. 2014. A longitudinal study investigating the prevalence of Staphylococcus aureus genotype B in seasonally communal dairy herds. J. Dairy Sci. 97:41844192. https://doi.org/10.3168/jds.2013-7291.

Zadoks, R. N., W. B. Van Leeuwen, D. Kreft, L. K. Fox, H. W. Barkema, Y. H. Schukken, and A. Van Belkum. 2002. Comparison of Staphylococcus aureus isolates from bovine and human skin, milking equipment, and bovine milk by phage typing, pulsed-field gel electrophoresis, and binary typing. J. Clin. Microbiol. 40:38943902. https://doi.org/10.1128/JCM.40.11.3894-3902.2002. 